\title{
Performance and plasma urea nitrogen of immunocastrated males pigs of medium genetic potential
}

\author{
Rendimiento y nitrógeno de urea en plasma de cerdos machos \\ inmunocastrados de potencial genético medio
}

\author{
Fabiana R Caldara, ${ }^{1 *}$ Ph.D, Rita KS Santos, ${ }^{1}$ M.Sc, Luan S Santos, ${ }^{1}$ B.Sc, \\ Luciana Foppa, ${ }^{1}$ B.Sc, Irenilza A Nääs, ${ }^{1}$ Ph.D, Rodrigo G Garcia, ${ }^{1}$ Ph.D, \\ Simone P Machado, ${ }^{1}$ B.Sc.
}

1Universidade Federal da Grande Dourados (UFGD), Faculdade de Ciências Agrárias (FCA), Zip Code
79823-350, Dourados, MS, Brazil. *Correspondence: fabianacaldara@ufgd.edu.br

Received: June 2014; Accepted: January 2015.

\begin{abstract}
Objective. A study was carried out to evaluate the performance and the plasma urea nitrogen (PUN) of male pigs of medium genetic potential for lean meat deposition in carcass, which underwent immunocastration. Materials and methods. Forty-five seventy-days old Large White $x$ Landrace crossbred were used. The pigs were distributed in a randomized design in three treatments: castrated males, females and immunocastrated males. Each treatment group was replicated three times with five pigs per replicate. The trial period was of 70 days, divided into phases of growing (70 to 110 days old) and finishing (111 to 140 days old). The pigs were weighed four times: at the beginning of the trial, at the first immunocastration vaccine dose ( 80 days old), at the second immunocastration vaccine dose ( 110 days old) and just before slaughter ( 140 days old). Blood samples were taken on the same day that the animals were weighed. Results. Between 80 and 110 days old, there was an increase in PUN value, only for castrated males and females. No differences were found in weight gain between the studied groups within the periods. Immunocastrated males had lower feed intake than females and these had a lower feed intake than castrated males. To 110 days old, immunocastrated animals showed feed conversion ratio similar to females and better than castrated males. However, after the second dose of the vaccine, feed conversion was similar between groups. Conclusions. The benefits of immunocastration are prominent in animals with low to medium genetic potential.
\end{abstract}

Key words: Castration, feed conversion, feed intake, immunocastration, swine production, weight gain (Source: USDA).

\section{RESUMEN}

Objetivo. Se realizó un estudio para evaluar el rendimiento y la concentración de urea en plasma (PUN) de los cerdos machos de medio potencial genético de carne magra en la canal sometidos a la inmunocastración. Materiales y métodos. Se utilizaron 45 cerdos de 70 días de edad Landrace $x$ Large White. Los animales se distribuyeron en un diseño completamente al azar con tres tratamientos: machos castrados, hembras y machos inmunocastrados. Cada tratamiento consistió en tres repeticiones, con cinco animales por réplica. El período experimental fue de 70 días, divididos en las etapas de crecimiento (70 a 110 días de edad) y terminación (111 a 140 días de edad). Los cerdos fueron pesados cuatro veces: al inicio del experimento, en la primera dosis de vacuna de inmunocastración ( 80 días de edad), en la segunda dosis de la vacuna de inmunocastración (110 días de edad) y antes 
de el sacrificio (140 días de edad). Las muestras de sangre se recogieron en el mismo día en que se pesaron los animales. Resultados. Entre 80 y 110 días de edad, hubo un aumento en la cantidad de PUN, sólo para machos castrados y hembras. No hubo diferencias en la ganancia de peso entre los grupos en ninguno de los períodos estudiados. Machos inmunocastrados tuvieron menor consumo de alimento que las hembras y éstas mostraron un menor consumo que los machos castrados. En 110 días de edad, los animales inmunocastrados mostraron la conversión de alimento similar a las hembras y mejor que los machos castrados. Sin embargo, después de la segunda dosis de la vacuna, la conversión alimenticia fue similar entre los grupos. Conclusiones. Los beneficios de inmunocastración son prominentes en animales con bajo a médio potencial genético

Palabras clave: Castración, conversión alimentícia, consumo de alimento, inmunocastración, producción porcina, ganacia de peso (Source: USDA).

\section{INTRODUCTION}

Surgical castration of young male pigs is a common practice in swine production worldwide. However, castrated male pigs have feed conversion efficiency and nitrogen retention impaired and they present lower lean: fat ratio than boars, which makes production significantly more expensive. The boars have the capability of high protein retention caused by the anti catabolic effect of gonadal steroids. The gonadal steroids influence the balance between protein synthesis and breakdown in favor of a high protein deposition (1). The anti catabolic effect of androgens, and thus the improved N-retention, is partly explained by the fact that androgens antagonize glucocorticoids and their catabolic functions (2).

Surgical castration without anesthesia has become an animal welfare issue and has been banned in many countries $(3,4)$. However, anesthesia may promote acute pain during castration and does not eliminate stress and discomfort due handling the animals before surgery and it will not prevent the chronic postcastration pain $(5,6)$. Although these factors produce significant importance to its progressive elimination in swine production, problems associated with boar taint, still are successfully solved by the adoption of the surgical castration. The odor is associated with sexual maturity and swine male hormones production, making the meat of uncastrated pigs unsuitable for human consumption (7).

It is clear that alternatives to the surgical castration of pigs need to be found. They must have practical application, be economically viable, do not present adverse impacts to the productive performance of the animals and meet consumer requirements and principles of welfare animal. The immunocastration is a procedure, which can replace surgical castration of male pigs, as it has proved effective in reducing the

\section{INTRODUCCIÓN}

La castración quirúrgica de los cerdos machos jóvenes es una práctica común en la producción porcina a nivel mundial. Sin embargo, los cerdos machos castrados presentan una eficiencia de conversión de alimentos y una retención de nitrógeno deficientes, además tienen un menor índice magra:grasa que los verracos que hace que la producción sea sustancialmente más costosa. Los verracos tienen la capacidad de una alta retención de proteínas debida al efecto anti-catabólico de los esteroides gonadales. Los esteroides gonadales influyen en el balance entre la síntesis y la descomposición de proteínas, favoreciendo una alta deposición de proteínas (1). El efecto anticatabólico de los andrógenos, y por lo tanto la retención de nitrógeno mejorada, se puede explicar parcialmente por el hecho de que los andrógenos antagonizan a los glucocorticoides y a sus funciones catabólicas (2).

La castración quirúrgica sin anestesia se ha convertido en un asunto de bienestar de los animales y ha sido prohibida en varios países $(3,4)$. Sin embargo, la anestesia puede provocar dolores agudos durante la castración y no elimina ni el estrés ni el malestar en la manipulación de los animales antes de la cirugía, ni tampoco evita el dolor crónico post-castración $(5,6)$. Aunque estos factores le dan una importancia significativa a la eliminación progresiva de de ésta en la producción porcina, los problemas asociados al olor sexual aún pueden solucionarse exitosamente por medio de la adopción de la castración quirúrgica. El olor está asociado a la madurez sexual y a la producción de hormonas masculinas en porcinos machos, lo cual hace que la carne de cerdos no castrados sea inapropiada para el consumo humano (7).

Es claro que existe la necesidad de encontrar alternativas a la castración quirúrgica de los cerdos. Dichas alternativas deben tener una aplicación práctica, ser viables económicamente, 
concentration of the hormones responsible for the boar taint (8). It also allows the animals to have longer satisfactory performance and carcass characteristics than those of non-castrated males; generating positive productive impact on the pig production (9).

Many studies support the effectiveness of the immunocastration, which is used in animals of high genetic potential (pigs of commercial lines genetically improved, with potential for lean meat deposition in carcass greater than 56\%)(9-12), with benefits that are not automatically extended to pigs with lower performance.

The research aimed to evaluate the effects of immunocastration on performance parameters and plasma urea levels of medium genetic potential pigs.

\section{MATERIAL AND METHODS}

Study site and animals. A study was carried out at the Swine Experimental Sector, at the Agrarian Sciences College, Universidade Federal da Grande Dourados (Federal University of Grande Dourados), MS, Brazil, using 45 crossbreed of Landrace and Large White genetic strains pigs. The animals were 70 days old, with an average weight of $25.2 \pm 2.8 \mathrm{~kg}$, being 15 females and 30 males. All pigs were submitted at the same rearing conditions, in open sided pens with semiautomated feeders and nipple drinkers, concrete floor and a herd density of $0.8 \mathrm{~m}^{2} /$ animal.

Treatments and experimental design. The animals were distributed in a fully randomized experimental design with three treatments, and three replications with 15 pigs per treatment. The treatments were T1 (females), T2 (surgically castrated males), and T3 (immune-castrated males).

The pigs in the castrated group underwent the orchiectomy procedure on the seventh day of life. The group of immunocastrated animals were subjected to two doses of Vivax ${ }^{\circledR}$, which is a vaccine based on a synthetic analogue of $\mathrm{GnRH}$ coupled to a large carrier protein. It was applied subcutaneous in two dosages: the first at 60 days before slaughter ( 80 days old), and the second at 30 days before slaughter ( 110 days old).

Nutritional management and experimental period. The trial period lasted 70 days, divided into two phases: growing (from 70 to 110 days) and finishing (from 111 to 140 days). The experimental diets were based on corn and soybean meal and were formulated using the estar exentas impactos adversos en el rendimiento productivo de los animales, satisfacer las exigencias de los consumidores y cumplir con los principios del bienestar de los animales. La inmunocastración es un procedimiento que puede reemplazar a la castración quirúrgica de los cerdos machos y que ha demostrado ser efectiva para reducir la concentración de hormonas responsables del olor sexual (8). Además, permite que los animales tengan un mayor rendimiento satisfactorio y mejores características en la canal que los machos no castrados, lo cual genera un impacto positivo en la producción porcina (9).

Varios estudios respaldan la efectividad de la inmunocastración, utilizada en animales con un alto potencial genético (cerdos de líneas comerciales mejorados genéticamente, con un potencial de deposición de carne en la canal mayor al $56 \%)(9,12)$, con beneficios que no se extienden automáticamente a los cerdos con un menor rendimiento.

La investigación buscó evaluar los efectos de la inmunocastración en parámetros de rendimiento y de niveles de urea en plasma en cerdos con un potencial genético medio.

\section{MATERIALES Y MÉTODOS}

Lugar de estudio y animales. Se realizó un estudio en el Sector Experimental Porcino, en la Escuela de Ciencias Agrarias, Universidade Federal da Grande Dourados (Universidad Federal de Grande Dourados), MS, Brasil, utilizando 45 cerdos cruzados entre las cepas genéticas Landrace y Large White. Los animales tenías 70 días de edad, con un peso promedio de $25.2 \pm 2.8 \mathrm{~kg}$, donde 15 cerdos fueron hembras y 30 machos. Todos los cerdos fueron sometidos a las mismas condiciones de crianza, en corrales abiertos a los lados con alimentadores semiautomatizados y bebederos de pezón, piso de concreto y una densidad de rebaño de $0.8 \mathrm{~m}^{2} /$ animal.

Tratamientos y diseño experimental. Los animales se distribuyeron en un diseño experimental totalmente aleatorizado con tres tratamientos y tres réplicas usando 15 cerdos para cada tratamiento. Los tratamientos fueron T1 (hembras). T2 (machos castrados quirúrgicamente) y T3 (machos inmunocastrados).

Los cerdos en el grupo castrado fueron sometidos a un procedimiento de orquiectomía en su séptimo dúa de vida. El grupo de 
nutritional requirements according to Rostagno et al (13), for entire males during growth and for females in the finishing phase. These recommendations were adopted to ensure that both phases in all categories evaluated would be assisted in their nutritional requirements, thus opting for formulating rations based on the most demanding category in each phase. In the finishing phase were used the dietary recommendations for females, since the animals immunocastrated group after receiving the second dose of vaccine, have lower requirements for entire males. The diets and water were provided ad libitum throughout the trial (Table 1).

Table 1. Percentual diet composition and nutritional characteristics for growing and finishing pigs.

\begin{tabular}{lcc}
\hline \multicolumn{1}{c}{ Ingredients } & *Growing(\%) $*$ *Finishing (\%) \\
\hline Soybean meal 46\% & 27.60 & 22.00 \\
Corn & 68.50 & 75.30 \\
Soybean oil & 0.50 & 0.13 \\
NaCl & 0.40 & 0.35 \\
Dicalcium phosphate & 1.40 & 1.00 \\
Limestone & 0.71 & 0.60 \\
L-lysine HCl, 78.5\% & 0.40 & 0.25 \\
DL-methionine 98\% & 0.10 & 0.05 \\
L-threonine 98\% & 0.14 & 0.07 \\
Supplement vitamin and mineral & 0.25 & 0.25 \\
Nutritional calculated values & & \\
\hline Metabolizable energy (kcal/kg) & 3229 & 3237 \\
Crude protein (\%) & 18.4 & 16.2 \\
Ether extract (\%) & 3.46 & 3.25 \\
Crude fiber (\%) & 2.65 & 2.47 \\
Calcium (\%) & 0.70 & 0.55 \\
Available phosphorus (\%) & 0.36 & 0.28 \\
Sodium (\%) & 0.18 & 0.16 \\
Chlorine (\%) & 0.29 & 0.26 \\
Digestible Lysine (\%) & 1.14 & 0.26 \\
Digestible Methionine (\%) & 0.35 & 0.56 \\
Methionine + Cystine (\%) & 0.62 & \\
Digestible Threonine (\%) & 0.74 & 0.20 \\
Digestible Tryptophan (\%) & & \\
\hline & & 0.56 \\
\hline
\end{tabular}

*recomendation for entire males of high genetic potential and mean performance (average values for animals $30-70 \mathrm{~kg}$ ); $* *$ recommendation for females of high genetic potential and mean performance (average values for animals 70-100 $\mathrm{kg})$, according to Rostagno et al (13).

Vitamin and mineral supplement provide per $\mathrm{kg}$ : Folic acid - $167.0 \mathrm{mg}$; Vit. A 2.330.000 UI; B.H.T.- 32.700 mg; Selenium) - 66.7 mg; Choline - 43.300 mg; Pantothenic acid $-2.667 \mathrm{mg}$; Nicotinic acid $-5.567 \mathrm{mg}$; Vit. B12 $-66.700 \mathrm{mcg}$; Vit. B6 - 667 mg; Vit. B2- 1000 mg; Vit. B1 - 234 mg; Vit. K3 - 667 mg; Vit. E - 5000 IU; Vit. D3 - 833,000 IU; Biotine - $25 \mathrm{mg}$; Co - $500 \mathrm{mg} ; \mathrm{Cu}-87,500$ $\mathrm{mg} ; \mathrm{Zn}-50.000 \mathrm{mg} ; \mathrm{Fe}-50.000 \mathrm{mg} ; \mathrm{Mn}-20.000 \mathrm{mg}$; I - $750 \mathrm{mg}$

Evaluation parameters. The animals of the all experimental treatments were weighed four times, at the beginning of the trial, at the first immunocastration vaccine dose, at the second immunocastration vaccine dose, and at the day to the slaughter. The diets provided and feed remainder were weighed weekly to evaluate the performance, which was measured as the animales inmunocastrados fueron sometidos a dos dosis de $\operatorname{Vivax}^{\circledR}$, que es una vacuna con base en un análogo sintético de GnRH acoplado a una proteína portadora grande. Se aplicó subcutáneamente en dos dosis: la primera a 60 días antes de la matanza (80 días de edad) y la segunda a 30 días antes de la matanza (110 días de edad).

Manejo nutricional y periodo experimental. El periodo del estudio fue de 70 días divididos en dos fases: de crecimiento (desde los 70 a los 100 días) y de finalización (desde los 111 a los 140 días). Las dietas experimentales a base de maíz y harina de soya fueron formuladas utilizando requerimientos nutricionales conforme a Rostango et al (13) en todos los machos durante el crecimiento y en las hembras en la fase de finalización. Las anteriores recomendaciones se adoptaron para garantizar que ambas fases de todas las categorías estuvieran asistidas en términos de requisitos nutricionales, para así optar por formular las raciones con base en la categoría más exigente de cada fase. En la fase de finalización se utilizaron las recomendaciones dietéticas para las hembras, ya que los animales del grupo inmunocastrado tienen menores requerimientos que el resto del grupo de machos después de recibir la segunda dosis de la vacuna. Las dietas y el agua se suministraron ad libitum a lo largo del estudio (Tabla 1).

Parámetros de evaluación. Los animales de todos los tratamientos experimentales se pesaron cuatro veces, al inicio del estudio, en el momento de la primera dosis de vacuna de inmunocastración, en el momento de la segunda dosis de vacuna de inmunocastración y en el día de la matanza. Las dietas suministradas y el sobrante de los alimentos se pesaron semanalmente para evaluar el rendimiento, que se midió como el aumento de peso diario, al igual que la ingesta diaria de alimentos y la conversión de alimentos en cada etapa.

Se tomaron muestras de sangre por venopunción en tubos heparinizados en el mismo día en que se pesaron los animales. Antes de tomar las muestras, los lechones fueron puestos en ayunas desde las 18:00 h a las 07:00 h hasta el siguiente día. Desde las 07:00 h hasta las 08:00 h, los animales fueron alimentados ad libitum y volvieron a ser puestos en ayunas desde las 08:00 h hasta las 13:00 h, momento en el cual se realizó la toma de muestras de sangre. La sangre se centrifugó a 3000 rpm durante 15 min para obtener el plasma, que fue trasladado a tubos Eppendorf 
daily weight gain, daily feed intake and feed conversation rate at each stage.

Blood samples were taken in heparinized tubes, by the vein puncture on the same day of animal weighing. Before collection, piglets were fasted from 18:00 $\mathrm{h}$ to $07: 00 \mathrm{~h}$ in the following day. From 07:00 $\mathrm{h}$ to $08: 00 \mathrm{~h}$, the animals were fed ad libitum and returned to fast from 08:00 $h$ until 13:00 h, when it was started the blood sampling. The blood was centrifuged at 3000 rpm for 15 minutes to get the plasma, which was transferred to Eppendorf tubes $( \pm 1.5 \mathrm{ml})$ and stored in a freezer $\left(-18^{\circ} \mathrm{C}\right)$. The concentration of plasma urea nitrogen (PUN) was obtained using the enzymatic method (commercial kit).

Statistical analysis. The results were analyzed using the SAS 9.2 software (14). ANOVA was applied to mean values using the general linear model (GLM). The means were compared by Tukey test considering a $5 \%$ level of significance.

Ethical considerations. This investigation was conducted according to the guidelines established by the Ethical Committee on the Animal Use in Experimentation of the Universidade Federal da Grande Dourados (Brazil), under Protocol $N^{\circ} 031 / 2013$, in accordance with the ethical principles for animal experimentation, animal care and use.

\section{RESULTS}

No differences were found ( $p>0.05)$ for Plasma Urea Nitrogen (PUN) in the first two samplings (at the beginning of the trial and just before immunocastrated animals receive the first dose of vaccine) amongst the three animal groups.

However, for females and castrated males there was an increase in PUN after the second sampling. This might indicate a reduction in the efficiency of protein utilization from this stage, while, for immunocastrated males there was an increase in PUN which occurred only after the third sampling, after immunocastration vaccine second shot. This may indicate advantage in the utilization of dietary protein by this animal category in this period, between the first and second dose of vaccine (Table 2).

No difference $(p>0.05)$ was found in PUN results in 4th sampling between groups. This might indicate that the effect of vaccine second dose, in which immunocastrated animals begin to behave physiologically as castrated animal, may lead to the ability of retaining nitrogen and protein deposition in muscle similar to boars.
$( \pm 1.5 \mathrm{ml})$ y almacenado en un congelador $\left(-18^{\circ} \mathrm{C}\right)$. La concentración de nitrógeno ureico en plasma (PUN por su sigla en inglés) se obtuvo usando el método enzimático (kit comercial).

Análisis estadístico. Los resultados se analizaron utilizando el software SAS 9.2 (14). Se aplicó ANOVA a los valores medios utilizando el modelo lineal general (MLG). Las medias fueron comparadas aplicando la prueba de Turkey considerando un nivel de significancia del $5 \%$.

Consideraciones éticas. Esta investigación se realizó conforme a los lineamientos del Comité Ético sobre el Uso de Animales de la Universidade Federal da Grande Dourados (Brasil), bajo el protocolo $\mathrm{N}^{\circ}$ 031/2013, de acuerdo a los principios éticos de experimentación, cuidado y uso de animales.

\section{RESULTADOS}

No se encontraron diferencias $(p>0.05)$ en el nitrógeno ureico en plasma (PUN) en las primeras dos muestras (al inicio del estudio y justo antes de que los animales inmunocastrados recibieran la primera dosis de la vacuna) entre los tres grupos de animales.

Sin embargo, en hembras y en machos castrados hubo un aumento en el PUN después de la secunda muestra. Esto puede indicar una reducción en la eficiencia del uso de proteínas en esta etapa, mientras que en los machos inmunocastrados se vio un aumento en el PUN que ocurrió únicamente después de la tercera muestra, después de la segunda dosis de la vacuna de inmunocastración. Lo anterior puede indicar que existe una ventaja en la utilización de la proteína en la dieta por esta categoría de animales y en este periodo, entre la primera y la segunda dosis de la vacuna (Tabla 2).

Table 2. Plasma urea nitrogen (PUN) concentration $(\mathrm{mg} / \mathrm{dL})$ of pigs: castrated males, females and immunocastrated males in different periods of blood collection.

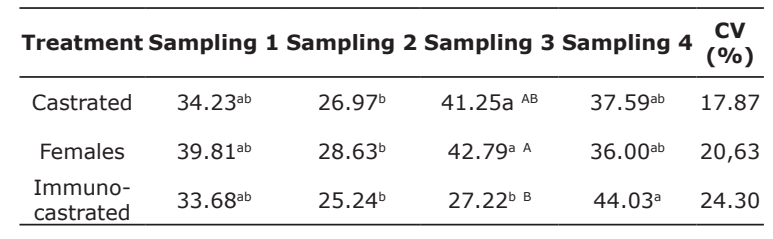

Means followed by lowercase letters in line and uppercase letters in columns differ by Tukey test at $5 \%$ probability $(p<0.05)$. Sampling 1: beginning of the experiment; Sampling 2: immediately before immunocastrated animals group receive the vaccine 1 st dose; Sampling 3: immediately before immunocastrated animals group receive vaccine 2 nd dose; Sampling 4: end of the experiment 
No difference ( $p>0.05)$ was found in average daily weight gain between immunocastrated males and other groups in all evaluated periods. Castrated males and females differed only in period 2 (80 to 110 days old), (Table 3 ).

Table 3. Daily weight gain (DWG), daily feed intake (DFI) and feed conversion rate (FC) in pigs: castrated males, immunocastrated males and females.

\begin{tabular}{lccccc}
\hline Variable & Period & Castrated & Female & $\begin{array}{c}\text { Immuno- } \\
\text { castrated }\end{array}$ & CV\% \\
\hline DWG (kg) & 1 & $0.748^{\mathrm{a}}$ & $0.703^{\mathrm{a}}$ & $0.709^{\mathrm{a}}$ & 12.71 \\
& 2 & $0.976^{\mathrm{a}}$ & $0.890^{\mathrm{b}}$ & $0.907^{\mathrm{ab}}$ & 6.88 \\
& 3 & $1.004^{\mathrm{a}}$ & $0.969^{\mathrm{a}}$ & $1.007^{\mathrm{a}}$ & 17.53 \\
& Total & 0.955 & 0.897 & 0.922 & \\
DFI(kg) & 1 & $1.737^{\mathrm{a}}$ & $1.536^{\mathrm{b}}$ & $1.321^{\mathrm{c}}$ & 1.35 \\
& 2 & $2.832^{\mathrm{a}}$ & $2.522^{\mathrm{b}}$ & $2.362^{\mathrm{c}}$ & 0.07 \\
& 3 & $4.152^{\mathrm{a}}$ & $3.850^{\mathrm{b}}$ & $3.771^{\mathrm{b}}$ & 0.05 \\
& FC & $3.241^{\mathrm{a}}$ & $2.950^{\mathrm{b}}$ & $2.817^{\mathrm{b}}$ & \\
& 1 & $2.301^{\mathrm{a}}$ & $2.147^{\mathrm{ab}}$ & $1.895^{\mathrm{b}}$ & 12.28 \\
& 2 & $2.902^{\mathrm{a}}$ & $2.842^{\mathrm{ab}}$ & $2.618^{\mathrm{b}}$ & 7.35 \\
& 3 & $4.151^{\mathrm{a}}$ & $4.001^{\mathrm{a}}$ & $3.570^{\mathrm{a}}$ & 12.18 \\
& Total & $3.351^{\mathrm{b}}$ & $3.239^{\mathrm{ab}}$ & $2.923^{\mathrm{a}}$ & \\
\hline
\end{tabular}

Means followed by different letters in line differ statistically from each other by Tukey test $(p>0.05)$. Period 1 - before the immunocastration vaccine shot 1 st dose (70-80 days old); Period 2 - between the 1st and 2 nd vaccine dose application (80-110 days old); Period 3 - after the immunocastration shot vaccine 2nd dose (110-140 days old)

Immunocastrated males showed lower feed intake than females and these, on the other hand, presented lower intake than castrated males in the first and second periods. In the third period, immunocastrated animals present feed intake similar to females, and lower than it was in the castrated group.

In the first and second periods, the immunocastrated males present feed conversion similar to females, and better than it was in the castrated group. After the second dose of the vaccine (period 3 ), the feed conversion was similar between treatments.

\section{DISCUSSION}

The reduction of PUN concentration reflects the superior nitrogen use efficiency and can be used to estimate the quantity and quality of dietary protein (15) and its increase may indicate inefficient use of amino acids (16).

Since the diets were formulated to comply with the boars' requirements for growing pigs and for females in the finishing phase (13), the greatest potential for utilization of amino acids dietary by
No se encontró ninguna diferencia $(p>0.05)$ en el promedio diario de aumento de peso entre los machos inmunocastrados y los otros grupos en ninguno de los periodos evaluados. Los machos castrados y las hembras sólo mostraron diferencias en el periodo 2 (de 80 a 110 días de edad) (Tabla 3).

Los machos inmunocastrados mostraron una menor ingesta de alimentos que las hembras y éstas, por otro lado, presentaron una ingesta menor a la de los machos castrados en el primer y segundo periodo. En el tercer periodo, los animales inmunocastrados presentaron una ingesta de alimentos similar a la de las hembras, a su vez menor a la ingesta del grupo castrado.

En el primer y segundo periodo, los machos inmunocastrados presentaron una conversión de alimentos similar a la de las hembras, que a su vez fue mejor a la del grupo castrado. Después de la segunda dosis de vacuna (periodo 3), la conversión de alimentos fue similar entre los tratamientos.

\section{DISCUSIón}

La reducción en la concentración de PUN refleja una eficiencia de uso del nitrógeno superior y puede ser utilizada para estimar la cantidad y la calidad de proteína en la dieta (15) y su aumento puede indicar un uso ineficiente de los aminoácidos (16).

Dado que las dietas se formularon para cumplir con los requerimientos de los verracos, los cerdos en crecimiento y las hembras en la fase de finalización (13), se hace evidente el mayor potencial para la utilización dietética de los aminoácidos por parte de los machos inmunocastrados después de recibir la segunda dosis de la vacuna. Esta diferencia se traduce en el aumento de sus requerimientos nutricionales, ya que los valores de PUN en los animales castrados y las hembras en la primera fase indican que dichos animales no pudieron mantener el nitrógeno en la misma medida que los animales inmunocastrados.

La maximización en la utilización eficiente de los aminoácidos es de importancia considerable para los productores porcinos, ya que la provisión de aminoácidos es uno de los puntos más relevantes para el costo final del alimento. La concentración de nitrógeno ureico en plasma puede ser utilizada para evaluar la calidad de la proteína consumida y puede ser utilizada como un indicador de la máxima utilización de aminoácidos (16). 
immunocastrated males, after receiving the second dose of vaccine, becomes clear. This difference translates their increased nutritional requirement, since increased PUN values for castrated and females in the first phase indicate that these animals were not able to maintain nitrogen in the same proportion that immunocastrated animals.

The maximization of amino acids efficient utilization has considerable importance for swine producer because the amino acids supply is one of the most relevant items on the final cost of feed. The concentration of urea nitrogen in plasma can be used to evaluate the quality of protein consumed and may be used as an indicator of maximum amino acids utilization (16). In this way, concentration of PUN is particularly useful in comparing the protein utilization effective for different swine's groups (females and castrated males immunocastrated males).

Disagreeing from the present study other researchers have demonstrated positive effects on daily weight gain and immunocastrated males showed superior performance about $8.3 \%$ and $32 \%(8,17)$ respectively compared to castrated males. The superior performance of immunocastrated males in relation to castrated males, in the delayed finishing phase, can be considered an indicative of nutrient requirements for these different groups. Both studies used animals with superior genetic potential while in the present study the animals were from medium genetic potential. These results suggest that the benefits of immunocastration may not be extended in the same proportion to the low genetic potential animals for both weight gain and lean meat deposition in the carcass.

Comparing the effects on the pigs' performance, Santos et al (17) found that immunocastrated swine showed better feed-conversion than castrated males. Immunocastrated animals were more effective in the nutrients use than barrows, even after the second immunization dose, similar to the response observed by other authors (12). The authors refer these results to the temporary existence of residual effect of endogenous anabolic hormones in immunocastrated pigs.

Castrated male pigs have higher feed consumption than the entire males (18), whose response has been related to low testosterone concentration in these animals (8). Furthermore, it has been observed an increase in daily amount of feed ingested by immunocastrated males when compared to castrated animals after the second dose of immunocastration vaccine (19). This fact may be related to the sharp decline in testosterone levels in immunocastrated pigs.
De esta manera, la concentración de PUN es particularmente útil para comparar la utilización de proteínas efectiva en los distintos grupos porcinos (hembras, machos castrados y machos inmunocastrados).

Discrepando del presente estudio, otros investigadores han demostrados efectos positivos en el aumento de peso diario, y los machos inmunocastrados mostraron un rendimiento superior al de los machos castrados, $8.3 \%$ y $32 \%$ $(8,17)$ respectivamente. El rendimiento superior de los machos inmunocastrados en comparación con los machos castrados, en la parte tardía de la fase de finalización, se puede considerar como un indicador de los requerimientos de nutrientes de los distintos grupos. Ambos estudios usaron animales con un potencial genético superior, mientras que en el presente estudio los animales poseían un potencial genético medio. Estos resultados sugieren que los beneficios de la inmunocastración pueden no extenderse en la misma proporción en los animales con potencial genético bajo, tanto en el aumento de peso como en la deposición de carne magra en la canal.

Comparando los efectos sobre el rendimiento de los cerdos, Santos et al (17) encontró que los porcinos inmunocastrados demostraron una mejor tasa de conversión de alimentos que los machos castrados. Los animales inmunocastrados fueron más eficientes en el uso de nutrientes que los cerdos castrados, incluso después de la segunda dosis de inmunización, respuesta similar a la observada por otros autores (12). Los autores atribuyen estos resultados a la existencia temporal de un efecto residual de hormonas anabólicas endógenas presente en los cerdos inmunocastrados.

Los cerdos machos castrados tienen un mayor consumo de alimentos que todos los machos (18), cuya respuesta se ha correlacionado con una baja concentración de testosterona en estos animales (8). Además, se ha observado un aumento en la cantidad diaria de alimentos ingerida por los machos inmunocastrados en comparación con los animales castrados después de la segunda dosis de la vacuna de inmunocastración (19). Este hecho puede estar relacionado a la vertiginosa disminución en los niveles de testosterona observada en los cerdos inmunocastrados. Sin embargo, esta respuesta no se observó en el presente estudio, lo cual coincide con los resultados que obtuvo Janos et al (20).

En un estudio de machos sometidos a inmunocastración, los investigadores encontraron que en el momento de la segunda dosis de 
However, this response was not observed in the present study, agreeing with the result obtained by Jaros et al (20).

In a study involving males undergoing to the immunocastration, the reserachers found that at the time of the second dose of immunogenic vaccine, $85 \%$ of treated males had a serum testosterone level above $2 \mathrm{nM}$. Two weeks after the second vaccination, only $6 \%$ of the animals had testosterone concentrations above $2 \mathrm{nM}$, which did not differ from castrated males. This may explain the results of the present study, in which immunocastrated animals showed similar performance than females and higher than castrated males in the period before the second dose of vaccine, becoming physiologically as a castrated animal after the second immunization (8).

Researchers (10) compared the growth performance and carcass characteristics of castrated males, immunocastrated males and boars. The authors found for immunocastrated animals that the feed intake and feed conversion values are similar to the reported for boars, but lower than those found in castrated males. This may indicate that there is better efficiency in nutrients utilization and higher daily weight gain in boars than in castrated males, found especially during the late finishing phase.

Immunocastrated males presented lower plasma urea nitrogen concentrations in relation to females and castrated males, before to the second dose of the vaccine. The best utilization of dietary protein resulted in a performance benefits, with a reduction in the feed intake and the feed conversion, even for animals of low to medium genetic potential.

\section{Acknowledgments}

FUNDECT - Fundação de Apoio ao Desenvolvimento do Ensino, Ciência e Tecnologia do Estado de Mato Grosso do Sul, for the financial support to conduct the research. la vacuna de inmunocastración, $85 \%$ de los machos tratados tenían un nivel de testosterona en suero de $2 \mathrm{nM}$. Dos semanas después de la segunda vacuna, sólo el $6 \%$ de los animales tuvieron concentraciones de testosterona superiores a $2 \mathrm{nM}$, nivel que no fue distinto al de los machos castrados. Esto podría explicar los resultados de este estudio, en el cual los animales inmunocastrados mostraron un rendimiento similar al de las hembras y superior al de los machos castrados antes de la segunda dosis de la vacuna, tornándose fisiológicamente como animales castrados después de la segunda inmunización (8).

Algunos investigadores (10) compararon el rendimiento en el crecimiento y las características de la canal de machos castrados, machos inmunocastrados y verracos. Los autores encontraron que en los animales inmunocastrados los valores de ingesta de alimentos y los de conversión de alimentos son similares a los encontrados en verracos, pero menores a los encontrados en machos castrados. Esto podría indicar que hay una mayor eficiencia en la utilización de nutrientes y un mayor aumento de peso diario en verracos que en machos castrados, lo cual se observó particularmente en la fase de finalización.

Los machos inmunocastrados presentan menores concentraciones de nitrógeno ureico en plasma en relación con las hembras y los machos castrados, antes de la segunda dosis de la vacuna. La mejor utilización de la proteína alimentaria presenta beneficios, con una reducción en la ingesta de alimentos y la conversión de alimentos, incluso en animales de potencial genético de bajo a medio.

\section{Agradecimientos}

FUNDECT - Fundação de Apoio ao Desenvolvimento do Ensino, Ciência e Tecnologia do Estado de Mato Grosso do Sul, por el apoyo financiero brindado para realizar la investigación.

\section{REFERENCES}

1. Van Weerden EJ, Grandadam JA. The effect of an anabolic agent on N-deposition, growth, and slaughter quality in growing male pigs. Environ Qual Saf Suppl 1976; (5):115-22.

2. Chen SY, Wang J, Yu G, Liu W, Pearce D. Androgen and glucocorticoid receptor heterodimer formation. J Biol Chem 1997; 272(22):14087-14092.
3. Rault JL, Lay Jr DC, Marchant-Forde JN. Castration induced pain in pigs and other livestock. Appl Anim Behav Sci 2011; 135(3):214-225.

4. Bauer A, Lacorn M, Danowski K, Claus R. Effects of immunization against $\mathrm{GnRH}$ on gonadotropins, the GH-IGF-I-axis and metabolic parameters in barrows. Animal 2008; 2(8):1215-1222. 
5. Puppe B, Schön PC, Tuchscherer A, Manteuffel G. Castration-induced vocalisation in domestic piglets, Sus Scrofa: complex and specific alterations of the vocal quality. Appl Anim Behav 2005; 95(1,2):67-78.

6. Thun R, GajewskI Z, Janett F. Castration in male pigs: techniques and animal welfare issues. J Physiol Pharmacol 2006; 57(8):189-194.

7. Zamaratskaia G, Squires EJ. Biochemical, nutritional and genetic effects on boar taint in entire male pigs. Animal 2009; 3(11):1508-1521.

8. Dunshea FR, Colantoni C, Howard K, McCauley I, Jackson P, Long KA, et al. Vaccination of boars with a $\mathrm{GnRH}$ vaccine (Improvac) eliminates boar taint and increases growth performance. J Anim Sci 2001; 79(10):2524-2535.

9. Caldara FR, Moi M, Santos LS, Almeida Paz ICL, Garcia RG, Nääs IA, et al. Carcass Characteristics and Qualitative Attributes of Pork from Immunocastrated Animals. Asian Australas. J Anim Sci 2013; 26(11):1630-1636.

10. Pauly C, Spring $P, O^{\prime}$ Doherty $V$, Ampuero Kragten S, Bee G. Growth performance, carcass characteristics and meat quality of group-penned surgically castrated immunocastrated (Improvac ${ }^{\circledR}$ ) and entire male pigs and individually penned entire male pigs. Animal 2009; 2(7):1-10.

11. Gispert M, Oliver MA, Velarde A, Suarez P, Perez J, Font i Furnols $M$. Carcass and meat quality characteristics of immunocastrated male, surgically castrated male, and entire male pigs. Meat Sci 2010; 85(4):664-670.

12. Škrlep $M$, Šegula $B$, Prevolnik $M$, Kirbiš $A$, Fazarinc G, Čandek-Potokar M. Effect of immunocastration (Improvac ${ }^{\circledR}$ ) in fattening pigs II: Carcass traits and meat quality. Slov Vet Res 2010; 47(2):65-72.
13. Rostagno HS, Albino LFT, Donzele JL, Gomes PC, Oliveira RF, Lopes DC, et al. Tabelas Brasileiras para aves e suínos. Composição de alimentos e exigências nutricionais. 3. ed. Minas Gerais, Viçosa: Universidade Federal de Viçosa; 2011

14. SAS. Statistical Analysis System [CD-ROM]. SAS/ Version 6. 6th ed. Cary, North Carolina, USA: SAS Inst, Inc; 2001.

15. Moreira I, Sartori IM, Paiano D, Martins RM, Oliveira GC. Utilização do farelo de algodão, com ou sem a adição de ferro, na alimentação de leitões na fase inicial (15-30 kg). R Bras Zootec 2006; 35(3):1077-1084.

16. Moreira I, Kutschenko M, Furlan AC, Murakami AE, Martins EN, Scapinello C. Exigência de lisina para suínos em crescimento e terminação, alimentados com rações de baixo teor de proteína, formuladas de acordo com o conceito de proteína ideal. Acta Sci - Anim Sci 2004; 26(4):537-542.

17. Santos AP, Kiefer C, Martins LP, Fantini CC. Restrição alimentar para suínos machos castrados e imunocastrados em terminação. Ciênc. Rural 2012; 42(1):147-153.

18. Pauly C, Spring $P, O^{\prime}$ Doherty $V$, Ampuero Kragten S, Bee G. Performances, meat quality, and boar taint of castrates and entire male pigs fed a standard and a raw potato starch-enriched diet. Animal 2008; 2(11):1707-1715.

19. Zamaratskaia G, Andersson HK, Chen G, Andersson K, Madej A, Lundström K. Effect of a gonadotropin-releasing hormone vaccine (improvacTM) on steroid hormones, boar taint compounds and performance in entire male pigs. Reprod Domest Anim 2008; 43(3):351-359.

20. Jaros $P$, Bürgi Stärk KDC, Claus R, Hennessy D, Thun R. Effect of active immunization against GnRH on androstenone concentration, growth performance and carcass quality in intact male pigs. Livest Prod Sci 2005; 92(1):31-38. 